\title{
Development Of The Banking Market In Albania
}

\author{
Alqi NAQELLARI ${ }^{1}$, Dr. Sokol PACUKAJ ${ }^{2}$, Ms.Elona SHAHINI ${ }^{1}$
}

\begin{abstract}
The purpose of this research is to analyze the development in banking sector in Albania since its strands and up to the present day. To highlight its role and influence in the Albanian Economy. The materials that are used are mainly taken by the Bank and INSTAT, Annual Statistical Reports, Monthly, Annual Reports and other materials needed for research. Methods used are mainly looking for methods of description, comparison, analysis and synthesis, the Gini index, Pearson, HHI, CR etc. The achieved results. Albanian Banking System is originated in 1850. Is divided into several periods. We have taken in the analyze the occurrences after 2003. There are 3 coins circulating in Albania. The banking system is concentrated in two poles, six leader banks and 10 with satellite role. The effect of the monetary policy transmission is low BOA for inflation, the cost and distribution of loans and the growth of economy. In conclusion, the banking system is deformed. Should be create a bank with state capital and gradually eliminate foreign currency deposits and loans.
\end{abstract}

Keywords: banking market, credit, deposit, styptic and expansionary monetary policy, inflation, unemployment, transmission effect,

\section{The purpose of the research.}

The purpose of this study is to make an analysis of the dynamics of the banking system by the creation until today. Focus on the analysis of the banking market from 2004 to 2014. To analyze the role of commercial banks in the Albanian economy through increased lending by analyzing their structure and distribution, by district, branch and currency. Very Briefly we will analyze the effect of monetary policy trasmisionit of commercial banks. Determine which are the achievements and what this system has weaknesses. Through determination of the weaknesses of the perspective given his thoughts on the economy and interest Albanian citizens.

Methods used. The methods used are the methods of description, analysis and synthesis. In determining the number of indicators we used the method of correlation, Pearson coefficient, then ignored the CR concentration, HHI and HTI. Data obtained by the Bank and INSTAT.

\section{History of Albanian monetary market development from 1850 until today. The first period from 1850 to 1913.}

History of the banking system is earlier. It dates back to $1850^{1}$. "The first bank in Albania was founded in 1850 in the city of Vlora Bohatka family" ("The Bankers Almanac And Book Year "For 1935 -36, The Ninety-First Year of Publication). On page 716 of the Almanac cited for Albania, saying: "PI Bohatka, Valona Albania, originally

1 Departament of Economy, Mediterranean University of Albania, Blv."Gjergj Fishta”. Nr.52 1023, Tirana

${ }^{2}$ Aleksander Moisiu, University of Durres, Durres, Albania. 
established in 1850, Pandeli Bohatka partner, Eleftherios K. Bohatka proxy holder, telegrams "Bohatka, Valona" codes; A.B.C. 5th edition; privately, agent London - Bank of Athens, agent New Yorker - National City Bank of New York. "On this page almanac presented four banks:

Private banks Bohatka 1850

Private banks Philandelphia USA 1764

Romanian Bank 1872

Birmingham Bank USA in 1887.

The data shows only one bank is older than our bank raised at Vlora Albania. Although the first attempts currency, payments and banks dating back to the early nineteenth century. On 4 February $1863^{2}$ the Imperial Ottoman Bank was established that issued bank notes convertible into gold. This raised bank branches in all the empire as Albanian vilayets in Ioannina, Bitola, Skopje and Shkodra. In 1888 he established the Agricultural Bank of the Ottoman Empire that stretched its operations through branches and agencies in the cities of Berat, Elbasan, Kavaja, Korca, Shkodra etc. In 1912 this bank were given Albanian farmers kidney 6.7 million gold loan, most long-term return ${ }^{3}$.

\section{$>\quad$ Second period $1913-1944$}

Albania had a central bank institution (the National Bank of Albania) in 1913. It was created as a result of the agreement of the Government of Ismail Kamal, Carol Pitner Oskar Pollak, Wienner Bank Verein representative acting on behalf of the Austrian banking group -Hungarian and Guido Pietro Fenolio Ansbaher representative of Banca Commerciale Italiana, acting on behalf of the Italian banking group. This institution did not live long due to the political conditions of the time and due to the onset of the First World War. National Bank of Albania was alive, perform the following actions over: purchase of securities, currencies, precious metals, goods trade for its own account and others, right of offering advance for goods insurance, securities, etc. It taked award over accepting deposits and loan companies and commercial enterprises, industrial, financial and agricultural. The emission performance over the guaranteed bonds and mortgage operations performance. NBA had exclusive right to issue banknotes in English and French. Bank was the sole fiscal agent of the government, both domestically and abroad. It has right to trade on behalf of the government treasury bills and other paper bills. Events happended at this time, as the outbreak of the Balkan Wars and the First World War turned the country into a battlefield. In these circumstances, the National Bank of Albania, before long, will close its operations ${ }^{4}$.

The history of the Albanian national currency at a time starts with the creation of the National Bank of Albania, constituted on September 2, 1925. The Bank was established with the signing of the relevant Convention between the Italian financial group headed by Mario Alberti and the Government of Ahmet Zogu. Convention defining the functions of the institution, other than credit, issuing banknotes course Albanian legal fees and issuance of coins of gold and other metals, with exclusive rights.

This can be called the first institution issuers national currency, but history proves our

\footnotetext{
1160 years bank in Albania. Shaska Fahri2011.

2 Banks as Financial intermediant. Meka Elvis

${ }^{3}$ Zarshati Orhan. Born of National Comercial Bank. Tirana 2011

${ }^{4}$ The history of Bank of Albania. Tirana 2003. Author Group (Red.Pro.Dr.Beqir Meta)
} 
people before cutting the currencies in the fourth century BC, by Dyrrahu (Durres) and Apollonia (Pojan near Fier), the cities of Illyria.

In 1925 when the bank was established in Albania circulated a host of currencies of different countries, to the National Bank of Albania took steps to replace these with Albanian single currency. As the official monetary unit was assigned Franc gold, with its subdivisions (Lek and cents, 1 gold franc was worth 100 cents and 5 ALL) and its multiples of 5, 20 and 100 gold francs. First banknotes issued was cutting it with ALL $5 / 1$ gold franc. It proved short-lived because of objections voiced by the Albanian government on the time shown on the eagle, which in contrast to the double-headed eagle, the symbol of our nation, eagle pose a Roman style head. In 1925, it resumed its activities under the name National Bank of Albania, with its administrative center in Durres and Administrative Committee in Rome. The restoration of the bank became a reality as a result of the agreement concluded by Mufid LIBOHOVA on behalf of the Albanian Government and Mario Albert on behalf of the Italian financial group.

\section{In February 1926, became the first circulation of the Albanian national.}

During this period, the National Bank of Albania implemented the gold standard meant that the notes are converted into gold and foreign currencies strong dollar, lira, pound, etc. Besides the issue function, perform the functions of this bank credit, where during a 10-year period acted under monopoly conditions, and from 1938 was found in competition with the Bank of Naples and National Bank of Labour.

Of particular interest is the project of creation of the National Bank of Albania, a project that begins in 1922, when the Albanian government addressed the League of Nations to assess the opportunities for foreign investment in Albania, with the conclusions of the report which proposed the creation of a bank, sending foreign experts for setting up the bank and ending with the relevant agreement and the start of operation of the bank in 1925. Particular interest, present the facts about the activities of this bank until 1944.

\section{$>\quad$ Third period 1944-1992 centralized banking system.}

This period is a layered banking system. In 1945, the Presidency of the Antifascist National Liberation Council adopted the law on the cancellation of the National Bank of Albania and its shares, which opened the way to the nationalization of the Bank. On January 3, 1945, was approved by the organic law of the Albanian State Bank, with the attributes of a central bank and a commercial bank simultaneously. After World War II until 1990, the State Bank of Albania supported the development program of the socialist economy, which was characteristic of the extreme centralization of the system in state hands. During the years 1949-1955, issued four editions B.SH.SH government bonds with 20 years to maturity. On January 1, 1979 was established as an institution Agricultural Bank credit and payment for cooperatives and agricultural enterprises ${ }^{6}$. Agricultural Bank lending enjoyed monopoly enterprises and agricultural cooperatives. Links between these banking institutions were very strong contingent. Deposits Cash population at the Institute of Security Savings used by the Albanian State Bank and Agricultural Bank for lending to their customers. Institute of Deposits Savings and Insurance does not credit the economy, while two other banks do not collect deposits from the population?

\footnotetext{
5. The same with ${ }^{4}$

6. Banks as Financial intermediant. Meka Elvis

7. The history of banks in Albania, Dhuci Orfea, Tirana 2012
} 


\section{The fourth period 1992-1997 Banks as "state monopoly.}

In the years 1992-1997 the banking sector was accompanied by deficient. Financial intermediation was limited. State-owned banks that dominate about $90 \%$ of the deposit market, perform limited functions of financial intermediation. Private banks were licensed in this period are: Italian Albanian Bank, Arab-Albanian Islamic Bank (1992), Dardania Bank (1993 after Italian Development Bank and Bank recently called Veneto), Tirana Bank and National Bank of Greece (1996), International Commercial Bank (1997). These banks were unwilling to attract deposits and granting loans in domestic currency $^{8}$. Lending to the economy was in a very low level. In this period were credited mainly state-owned enterprises. At such a level was the payment system for transactions through accounts in different branches of the same bank. For this reason the currency outside banks was much higher levels.

Fifth period 1998-2003 total privatization of the banking system.

Usury crisis of 1997 gave its consequences in the banking system. In 1998 the Agricultural Commercial Bank went bankrupt. Its bankruptcy was the result of mismanagement of loans, do not mix short term loans with long-term as well as the selection of its customers. In 1998 the Bank of Albania blocked giving credit from banks with state capital and began the process of privatization. So in 1999 the National Commercial Bank was privatized and in 2003 laws were passed for the privatization of shares owned by the Albanian State, the Italian-Albanian Bank and United Bank of Albania. At the end of 2003 was privatized Savings Bank which was bought by an international bank developed as Raiffeisen International. This transaction banking system turned on completely private. In this period, the Savings Bank owned about $52 \%$ of the market value of assets, $56 \%$ deposit and only $1 \%$ of the bank loan market. Savings Bank invest most of its assets in government bonds Albanian and little in the field of lending. She also owned about $80 \%$ of the market treasury bills. This position of the bank create a problem because up to 1 December 2003, the regulation of competition in Albania was governed by law no. 8044, dated 12.07.1995, On Competition". This law prohibiting the possession of a dominant position and in case of the existence of such a position called for the company in question. In these conditions, since the Savings Bank had a dominant position in the market it should be shared. But such a thing would harm its privatization process, therefore it was excluded from the provisions of the law for sharing it. It continued to be subject to the application of other provisions of Law, including horizontal and vertical agreements, concentration and abuse of dominant position (Competition Authority, 2007). However the moment of privatization of the Savings Bank also coincided with the entry into force of Law no. 9121 "On Protection of Competition", which does not prevent possession of a dominant position, but only the abuse of dominant position.

Another feature of this period was the increase in the number of banks through opening of new private banks. During this period, the number of second-tier banks and added seven new private banks: American Bank of Albania and Tirana branch of Alpha Bank (1998), ProCredit Bank, First Investment Bank and Emporiki Bank (1999), Credit Bank of Albania (2002), Credins (2003), smoothing the structure of the banking system so far dominated by foreign capital. Also in this period of banking activity has been expanded with the expansion of banks in the market, increasing both assets, the degree of financial intermediation and banking service quality itself. Positive trend of developments in the banking sector was improving credit market, which had steadily increasing lending to the 
private sector. This decrease was associated with non-performing loans to total loans, which in September 2002 amounts to 6.4\% compared with 32.7\% in 1999.

\section{4-2014 Period of six banking system completely privatized.}

In 1992, he began the reform of the banking system, as institutional reform to change the legal basis, through the adoption of the Law "On the Bank of Albania" and the law "On the banking system in the Republic of Albania". These laws over the banking system recorded a level in a two-tiered banking system, the Bank of Albania, was the first commercial bank and the Central Bank of the country, while the other three state-owned banks: Savings Bank, National Commercial Bank, Agricultural and Commercial Bank constituted commercial banks in the banking system. Savings Bank was the successor of Savings Institute with a new status as a universal bank. National Commercial Bank was a merger of domestic trade activity Albanian State Bank Commercial Bank Shqiptare.Mbi basis of these laws was open road licensing process of new private banks and banking regulation from the Central Bank.

Today, the banking system is the most important element of the Albanian financial system, whose assets represent about $97 \%$ of the assets of the entire financial system. We believe that these are the main stages of the development of banking system. Competition, efficiency and stability in the banking market in changing the structure of the system and competition in particular, will be summarized as follows.

\section{Features of the banking market after 2003.}

What are some of the main features of the banking system after 2003?

$=$ Are all foreign-owned banks, 16 banks only 3 of them have local capital.

$=$ Are all private banks and no capital of their state.

$=$ Banks are generally daughter and a few of them are parent bank. All have branches and agencies.

$=$ Exchange rate is flexible.

$=$ In circulation with the status of the local currency and dollar is circulating euro too.

$=$ Banking market is not competitive and monopolistic oligopoly.

During and after 2004 are licensed: National Bank (2004), Union Bank (2006). In 2007 the union was accomplished Italian-Albanian Bank with acquisition of American Bank of Albania.

The banking sector is diversified. His condition by shareholders, their share of equity ownership, origin of capital and the country have given in the following table:

State No.1 scatter plot of commercial banks by shareholders, their share of equity ownership, origin of capital and the country.

\begin{tabular}{|c|c|c|c|c|c|c|}
\hline No & Bank & Shareholders & $\begin{array}{l}\text { Capital } \\
\text { Owner }\end{array}$ & Owner & Origin & State \\
\hline 1 & Raiffeisen Bank & $\begin{array}{l}\text {-Raiffeisen Internacional } \\
\text {-Bank-Holding AG }\end{array}$ & 100 & $\mathrm{P}$ & $\mathrm{F}$ & Austry \\
\hline 2 & $\begin{array}{ll}\text { National } & \text { Comercial } \\
\text { Bank } & \\
\end{array}$ & Çalik Finanial Hizmetler A.S & 100 & $\mathrm{P}$ & $\mathrm{F}$ & Turkey \\
\hline 3 & $\begin{array}{lll}\text { United } & \text { Bank } \\
\text { Albania } & & \end{array}$ & $\begin{array}{l}\text {-Banka Islamike e Zhvillimit, Jeddah } \\
\text {-Shamil Bank of Bahrein } \\
\text {-Malaysian Co Business Fokus } \\
\text {-Dallah Albaraka Holding }\end{array}$ & $\begin{array}{l}55 \\
20 \\
6.34 \\
10 \\
\end{array}$ & $\begin{array}{l}\mathrm{P} \\
\mathrm{P} \\
\mathrm{P} \\
\mathrm{P}\end{array}$ & $\begin{array}{l}\mathrm{F} \\
\mathrm{F} \\
\mathrm{F} \\
\mathrm{F}\end{array}$ & $\begin{array}{l}\text { International } \\
\text { Institution. } \\
\text {-Arabia }\end{array}$ \\
\hline
\end{tabular}




\begin{tabular}{|c|c|c|c|c|c|c|}
\hline & & $\begin{array}{l}\text {-Saudi Brothers Commerce Co. } \\
\text {-Individë }\end{array}$ & $\begin{array}{l}2.5 \\
6.17\end{array}$ & $\begin{array}{l}\mathrm{P} \\
\mathrm{P}\end{array}$ & $\mathrm{F}$ & $\begin{array}{l}\text {-Malajzia } \\
\text {-Arabia } \\
\text {-Arabia }\end{array}$ \\
\hline 4 & Tirana Bank & $\begin{array}{l}\text {-Pireus Bank } \\
\text {-Dafnila SA } \\
\text {-Individual } \\
\end{array}$ & $\begin{array}{l}96.7 \\
1.3 \\
2 \\
\end{array}$ & $\begin{array}{l}\mathrm{P} \\
\mathrm{P} \\
\mathrm{P}\end{array}$ & $\begin{array}{l}\text { F } \\
F \\
F\end{array}$ & $\begin{array}{l}\text {-Greece } \\
\text {-Greece } \\
\text {-Greece }\end{array}$ \\
\hline 5 & $\begin{array}{l}\text { National Bank of } \\
\text { Greece }\end{array}$ & National Bank of Greece & 100 & $\mathrm{P}$ & $\mathrm{F}$ & -Greece \\
\hline 6 & Alpha Bank & Alpha Bank, Greece & 100 & $\mathrm{P}$ & $\mathrm{F}$ & -Greece \\
\hline 7 & Veneto Bank & Veneto Banka Holding & 100 & $\mathrm{P}$ & $\mathrm{F}$ & -Italy \\
\hline 8 & Pro Credit Bank & $\begin{array}{l}\text {-ProCredit Holding } \\
\text {-Commerzbank AG }\end{array}$ & $\begin{array}{l}80 \\
20 \\
\end{array}$ & $\begin{array}{l}\mathrm{P} \\
\mathrm{P}\end{array}$ & $\begin{array}{l}\mathrm{F} \\
\mathrm{F}\end{array}$ & $\begin{array}{l}\text {-Germany } \\
\text {-Germany }\end{array}$ \\
\hline 9 & $\begin{array}{l}\text { International } \\
\text { Comercial Bank }\end{array}$ & ICB Holding AG & 100 & $\mathrm{P}$ & $\mathrm{F}$ & -Zwis \\
\hline 10 & Emporiki Bank & Emporiki Bank, Greece & 100 & $\mathrm{P}$ & $\mathrm{F}$ & -Greece \\
\hline 11 & $\begin{array}{lll}\text { Credit } & \text { Bank of } \\
\text { Albania } & & \\
\end{array}$ & 3 individs & 100 & $\mathrm{P}$ & $\mathrm{F}$ & -Kuvajt \\
\hline 12 & Credins Bank & $\begin{array}{l}\text {-10 Individs } \\
\text {-Bushati sh.p.k } \\
\text {-Emigres SL } \\
\text {-BFSE Holding BV } \\
\text {-SECO(SIFEM) }\end{array}$ & $\begin{array}{l}65.77 \\
4.74 \\
4.15 \\
22.17 \\
3.17 \\
\end{array}$ & $\begin{array}{l}\mathrm{P} \\
\mathrm{P} \\
\mathrm{P} \\
\mathrm{P} \\
\mathrm{P}-\mathrm{S}\end{array}$ & $\begin{array}{l}\mathrm{N} \\
\mathrm{N} \\
\mathrm{F} \\
\mathrm{F} \\
\mathrm{F}\end{array}$ & $\begin{array}{l}\text {-Albania } \\
\text {-Albania } \\
\text {-Spain } \\
\text {-Holland } \\
\text {-Zwis } \\
\end{array}$ \\
\hline 13 & Popular Bank & $\begin{array}{l}\text {-Societe Generale } \\
-9 \text { individs }\end{array}$ & $\begin{array}{l}75 \\
25\end{array}$ & $\begin{array}{l}\mathrm{P} \\
\mathrm{P}\end{array}$ & $\begin{array}{l}\mathrm{F} \\
\mathrm{N}\end{array}$ & $\begin{array}{l}\text {-France } \\
\text {-Albania }\end{array}$ \\
\hline 14 & Union Bank & $\begin{array}{l}\text {-Unioni Financiar i Tiranës } \\
\text {-EBRD } \\
\text {-2 Individs }\end{array}$ & $\begin{array}{l}83.13 \\
12.5 \\
4.37\end{array}$ & $\begin{array}{l}\mathrm{P} \\
\mathrm{P} \\
\mathrm{P}\end{array}$ & $\begin{array}{l}\mathrm{N} \\
\mathrm{F} \\
\mathrm{N}\end{array}$ & $\begin{array}{l}\text {-Albania } \\
\text { Int. } \\
\text { Institution } \\
\text {-Albania } \\
\end{array}$ \\
\hline 15 & First investment Bank & $\begin{array}{l}\text {-First Investment Bank, Bulgaria } \\
\text {-Vitosha Ventures AD } \\
\text {-First Financial Brokerage House } \\
\text { Ltd }\end{array}$ & $\begin{array}{l}99.999 \\
0.0001 \\
0.0001\end{array}$ & $\begin{array}{l}\mathrm{P} \\
\mathrm{P} \\
\mathrm{P}\end{array}$ & $\begin{array}{l}\text { F } \\
F \\
F\end{array}$ & $\begin{array}{l}\text {-Bullgaria } \\
\text {-Bullgaria } \\
\text {-Bullgaria }\end{array}$ \\
\hline 16 & Intesa Sanpaolo Bank & $\begin{array}{l}\text {-Intesa Sanpaolo S.p.a } \\
\text {-EBRD } \\
\text {-Italian Association for foreign } \\
\text { enterprise }\end{array}$ & $\begin{array}{l}90.83 \\
7.78 \\
1.39\end{array}$ & $\begin{array}{l}\mathrm{P} \\
\mathrm{P} \\
\mathrm{P}\end{array}$ & $\begin{array}{l}\mathrm{F} \\
\mathrm{F}\end{array}$ & $\begin{array}{l}\text {-Italy } \\
- \\
\text { Institution } \\
\text { - Int. } \\
\text {-Italy }\end{array}$ \\
\hline
\end{tabular}

\section{Source: Open date Albania. Share Capital Structure and the Second Level Banks -} $\begin{array}{lllll}\text { extract NRC } & \text { May } & \end{array}$ In Albania develop their activity 16 banks with 21 shareholders from 15 countries and international institutions. From the above data we see that all banks are private, daughters, foreign where the largest share of occupied Greek Italian capital.

Fig.Nr.1 ownership structure of banks.

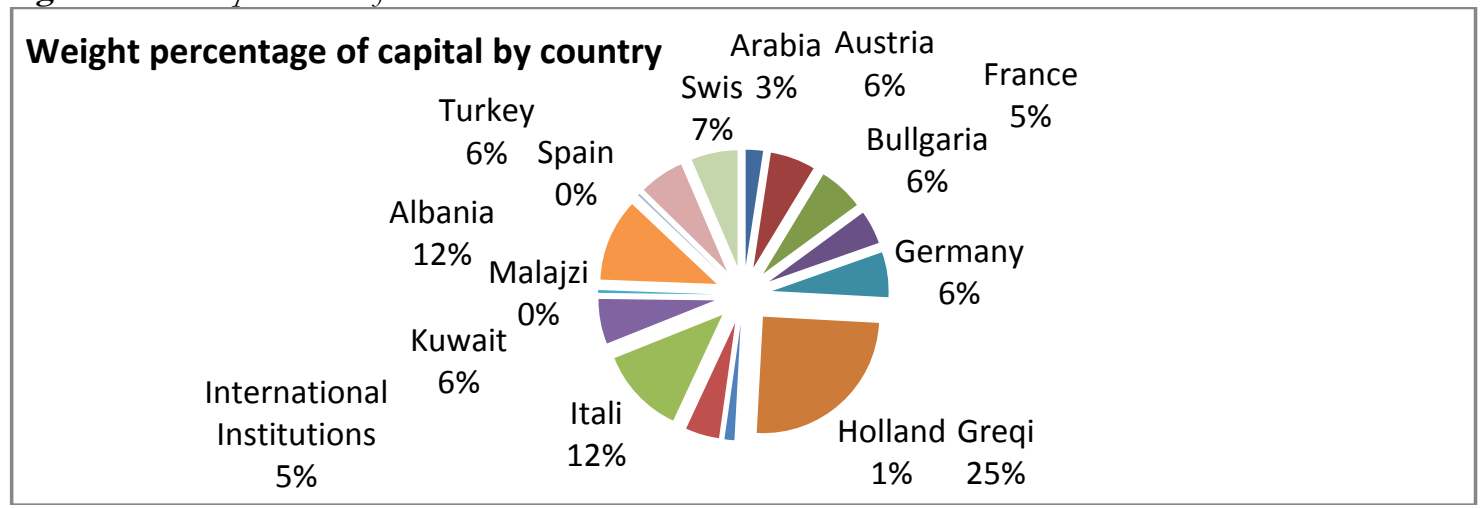


The introduction of foreign banks in the Albanian economy has led to increased competition and efficiency, increase the number of banking products and services. Today we have a number of products that did not exist before 1997. Increasing the number of bank branches and new agencies, are associated with the phenomenon of foreign investment in the form of sale of shares of some banks to the disadvantage of domestic capital. Positive is the fact that foreign investment in the banking market are accompanied by entities and banks that have experience in foreign markets, such as Raiffeisen Bank (Austria), Intesa Sanpaolo Bank (Italy), Piraeus Bank (Greece), Islamic Bank development (international financial institutions), Emporiki Bank (Greece), Societe Generale (France), European Bank for Reconstruction and development (international financial institution, etc.).

During these years the banking sector demonstrated a dynamic growth in various aspects which were associated with the expanding range of banking products and services. Not only have a vertical expansion in the number of services but also stretched horizontally across the territory of the Republic of Albania. Number of branches and agencies of banks amounted to 398 and 126, while the number of banks reaches 16 in late 2009. At first glance it seems like the market structure has changed from oligopolistic to monopolistic competition, but thanks to a few characteristics. Just as it would be seen inside this chapter features are closer to oligopoly than monopolistic competition.

Table No. 2 bank branches and agencies under

\begin{tabular}{|c|c|c|c|c|c|c|c|c|c|c|c|}
\hline \multirow{2}{*}{ No } & \multirow{2}{*}{ Banks } & \multicolumn{5}{|c|}{ Branch + Agency } & \multicolumn{5}{|c|}{ Branch } \\
\hline & & 2009 & 2010 & 2011 & 2012 & 2013 & 2009 & 2010 & 2011 & 2012 & 2013 \\
\hline 1 & $\begin{array}{l}\text { Raiffeisen } \\
\text { Bank } \\
\end{array}$ & 102 & 103 & 103 & 93 & 93 & 102 & 103 & 103 & 42 & 42 \\
\hline 2 & $\begin{array}{l}\text { National } \\
\text { Comercial } \\
\text { Bank }\end{array}$ & 58 & 59 & 58 & 60 & 60 & 27 & 27 & 53 & 58 & 58 \\
\hline 3 & $\begin{array}{l}\text { United Bank } \\
\text { of Albania }\end{array}$ & 6 & 6 & 6 & 6 & 6 & 4 & 4 & 4 & 4 & 4 \\
\hline 4 & Veneto Bank & 8 & 8 & 9 & 12 & 16 & 8 & 8 & 9 & 12 & 16 \\
\hline 5 & Tirana Bank & 47 & 52 & 56 & 56 & 56 & 43 & 49 & 52 & 56 & 56 \\
\hline 6 & $\begin{array}{l}\text { National Bank } \\
\text { of Greece }\end{array}$ & 30 & 30 & 27 & 27 & 27 & 5 & 5 & 5 & 27 & 27 \\
\hline 7 & $\begin{array}{l}\text { International } \\
\text { Comercial } \\
\text { Bank }\end{array}$ & 8 & 9 & 9 & 8 & 8 & 8 & 9 & 9 & 8 & 8 \\
\hline 8 & Alpha Bank & 48 & 48 & 46 & 42 & 42 & 48 & 48 & 46 & 42 & 42 \\
\hline 9 & $\begin{array}{l}\text { Intesa } \\
\text { Sanpaolo Bank }\end{array}$ & 37 & 32 & 31 & 32 & 32 & 19 & 17 & 17 & 32 & 32 \\
\hline 10 & $\begin{array}{ll}\text { Pro } & \text { Credit } \\
\text { bank } & \end{array}$ & 45 & 42 & 41 & 23 & 23 & 30 & 25 & 24 & 7 & 7 \\
\hline 11 & $\begin{array}{l}\text { Emporiki } \\
\text { Bank }\end{array}$ & 23 & 24 & 24 & 24 & 24 & 13 & 13 & 13 & 24 & 24 \\
\hline
\end{tabular}




\begin{tabular}{|c|c|c|c|c|c|c|c|c|c|c|c|}
\hline 12 & $\begin{array}{l}\text { Credit Bank of } \\
\text { Albania }\end{array}$ & 3 & 3 & 3 & 3 & 3 & 2 & 1 & 1 & 1 & 1 \\
\hline 13 & Credins Bank & 33 & 34 & 34 & 44 & 44 & 27 & 28 & 28 & 40 & 40 \\
\hline 14 & $\begin{array}{l}\text { Societe } \\
\text { Generale } \\
\text { Albania Bank }\end{array}$ & $\mathrm{x}$ & 42 & 44 & 42 & 42 & $\mathrm{x}$ & 42 & 44 & 42 & 42 \\
\hline & Popular Bank & 42 & & & & & 42 & $X$ & $\mathrm{x}$ & & \\
\hline 15 & Union Bank & 31 & 30 & 29 & 32 & 32 & 15 & 15 & 15 & 19 & 19 \\
\hline 16 & $\begin{array}{l}\text { First } \\
\text { Investment } \\
\text { Bank }\end{array}$ & 9 & 9 & 9 & 10 & 10 & 5 & 5 & 5 & 10 & 10 \\
\hline & Total & 530 & 531 & 529 & 514 & 518 & 398 & 399 & 428 & 424 & 428 \\
\hline & CR4 & 48.1 & 49.3 & 49.7 & 48.8 & 48.5 & 59.0 & 60.7 & 59.3 & 46.7 & 46.3 \\
\hline & CR6 & 64.5 & 65.2 & 65.8 & 61.5 & 61.0 & 73.37 & 74.4 & 76.2 & 66.0 & 65.4 \\
\hline
\end{tabular}

Source. Bank of Albania. Annual Report 2011, 2012. Ps concentration indicators in the last two rows are calculated by us.

The table shows the coverage of banking services throughout the territory of the country, shows that banks have increased the tendency of branches and their agencies every year and in every district. Increasing the number of branches and agencies has been accompanied by the introduction of new payment instruments

The use of payment instruments and their potential use show increasing trend.

In recent years the trend has increased the use of payment instruments and the potential to use. This is reflected not only in increasing the number of accounts but also in the growth of those accounts that can be done directly from the Internet. Number of accounts in total, foreign currency and in 2013 increased by $7.1 \%$. In this year the number of accounts accessed through the Internet has doubled. During 2013 are carried around 8.7 million customer payments with a total value of 3.624 billion, reflecting an annual growth of $9 \%$ and the number with a value decline by $5 \%$ compared with 2012 . Recently, services "home banking "are taking a stretch increasingly large Albanian market. After the presentation of this product in 2005, from a bank system at the end of 2013 were 11 banks that provide "home banking". Increase in number of customers accounts accessible from the Internet has been accompanied by an increase in the number of transactions "home banking" with 37\%, compared with 2012.

Table No.3 weight of customer payments, payments under the instrument during last 2 years

\begin{tabular}{|l|l|l|l|l|}
\hline \multirow{2}{*}{ Payment service for clients } & \multicolumn{2}{|l|}{ Year 2012 } & Year 2013 \\
\cline { 2 - 5 } & No & Value & No & Value \\
\hline I. Credit transfer for clients & $75.5 \%$ & $95 \%$ & $74 \%$ & $97 \%$ \\
\hline By which: & & & & \\
\hline $1 . \quad$ Transfer credit in paper form & $96.4 \%$ & $96.69 \%$ & $95 \%$ & $97.12 \%$ \\
\hline $\begin{array}{l}\text { 2. Transfer credit in the form of } \\
\text { non-paper }\end{array}$ & $3.50 \%$ & $3.32 \%$ & $5.00 \%$ & $2.88 \%$ \\
\hline II. Card payments at POS & $12.70 \%$ & $0.36 \%$ & $17.25 \%$ & $0.35 \%$ \\
\hline By which & & & & \\
\hline
\end{tabular}




\begin{tabular}{|ll|l|l|l|l|}
\hline 1. & Debit Card Payments & $59.20 \%$ & $35.30 \%$ & $57.78 \%$ & $45.87 \%$ \\
\hline 2. & Credit Card Payments & $40.70 \%$ & $64.60 \%$ & $42.22 \%$ & $54.13 \%$ \\
\hline III. & Direct Debitation & $6.40 \%$ & $0.10 \%$ & $7.76 \%$ & $0.61 \%$ \\
\hline IV. & Cheques & $0.72 \%$ & $2.20 \%$ & $0.57 \%$ & $2.35 \%$ \\
\hline $\begin{array}{l}\text { Total } \\
\text { ALL }\end{array}$ & Payment (I+II+III+IV) billion & $8,316,444$ & $3,633,448$ & $8,674,708$ & $3,624,336.64$ \\
\hline
\end{tabular}

Source: Bank of Albania (Reporting by banks, according to the "Methodology for reporting payment instruments ").

2013 has seen a 5\% increase in the number of cards in circulation, compared with last year. Separating cards by function, there is a growing expediting cards with a credit function, compared with those with a debit function, although the latter holding the largest share in the total cards in circulation $(92 \%)$. Increasing the number of bank cards is also accompanied by an increase in card transactions, which continue to occupy the major share transactions for cash withdrawals. During 2013, 13.2 million were processed card transactions (ATM and POS) with a total turnover of 130 billion. Of the total transactions constitute about $88.7 \%$ tërheqjecash ATM and only 11.3\% with customer payments in POS cards. Card payments at POS terminals show a predominance of the number of transactions conducted through debit cards by about $57.8 \%$.

Analysis of infrastructure offered by licensed banks to issue cards for 2013, dictates to a slight decrease in the number of ATMs by $0.12 \%$ yoy. On the other hand, the number of POS offered by licensed banks as receiving cards has increased by $7 \%$. Enterprise infrastructure developments within the banking system supporting electronic commerce in Alobania is on the establishment for the first time in the virtual POS Albanian market. The creation of these terminals is estimated to encourage the use of card payments and as a result, reduce the use of cash. From the banks' reports that at the end of 2013, the Albanian market operate three virtual POS.

Table No.4 weight of card transactions per terminal.

\begin{tabular}{|c|c|c|c|c|}
\hline \multirow[t]{2}{*}{ Card transactions by type of transaction } & \multicolumn{2}{|l|}{ Volume } & \multicolumn{2}{|c|}{ Value (Million All) } \\
\hline & 2011 & 2012 & 2011 & 2012 \\
\hline 1- ATM cash withdrawals & $10,778,879$ & $11,300,261$ & 106,660 & 109,609 \\
\hline 2- ATM deposits & 11.00 & 5 & 0.10 & 0.03 \\
\hline 3- Transfer orders through ATM & 277.00 & 80 & 5.72 & 0.68 \\
\hline 4- Cash withdrawals at POS terminals & 2,088 & 3,450 & 404 & 475 \\
\hline 5- Card payments at POS terminals & 750,379 & $1,107,425$ & 10,914 & 13,396 \\
\hline \multicolumn{5}{|l|}{ Of Wich } \\
\hline - debit card payments & 458,067 & 656,000 & 4,719 & 4,739 \\
\hline - payment by credit card & 292,330 & 451,425 & 6,195 & 8,657 \\
\hline Total card transactions & $11,531,652$ & $12,411,221$ & 117,980 & 123,481 \\
\hline
\end{tabular}

How is the degree of concentration of loans, deposits and profits. The degree of concentration of loans, deposits and profit is high. Below are some of the key indicators that reflect the degree of concentration.

CR Index. $\mathrm{CR}_{\mathrm{k}}=\sum_{i=1}^{k} S_{i}$ Characteristics. Includes participation of largest banks in the banking market. This is a simple method and requires less data compared with other indicators. For this reason it is one of the most frequently used in literature (unique index). Explanation. Index approaches 0 for an infinite number of subjects of the same size and approaches 1 if the larger entities constitute the entire industry. The rate of 
concentration varies from 0 to 100 . Usually used to classify these estimates market: There is no concentration. $0 \%$ means perfect competition or no monopolistic competition. If for example CR4 $=0 \%$, the fourth largest firm in the industry will not have any significant market share.

Full concentration. 100\% means an extremely concentrated oligopoly. If for example CR1 $=100 \%$, we have a monopoly.

Low concentration. $0 \%$ to $50 \%$. This category ranges from perfect competition to oligopoly.

Secondary concentration. $50 \%$ to $80 \%$. An industry in this range is likely a oligopoly.

High concentration. $80 \%$ to $100 \%$. This category ranges from oligopoly to a monopoly.

Herfindahl-Hirchman, HHI. Formula $H H I=\sum_{i=1}^{n} S^{2} i$. Information referred to as full index because it includes complete information for all distribution entities. Stresses the importance of larger entities, and weighted with a higher value smaller units. Explanation. The index is between $1 / \mathrm{n}$ and 1 reaching low limits when all subjects are the same size, and the upper limit catches in the case of monopoly. Market used to classify these estimates:

HHI index below 0,01 (or below 100) shows a very competitive market.

$\mathrm{HHI}$ index less than 0,15 (or 1,500) indicates a non-concentrated market.

HHI index between 0,15 to 0,25 (or 1500 and 2500 ) shows a moderate concentration.

HHI index over 0,25 (2500) shows that we have a high concentration.

Hall-Tideman, HTI. Formula. $H T I=1 /\left(2 \sum_{i=1}^{n} i s_{i}-1\right)$. Characteristics. Stresses the need to include the number of subjects that reflect competition in the market; a small number of entities representing the harsh conditions of entry into the banking industry and the opposite for a larger number of subjects. The market share of each company is weighted by its ranking.

Index tends 0 for an infinite number of subjects with equal size, and become the first in the case of monopoly.

Industrial concentration, CCI. $C C I=s_{i}+\sum_{i=2}^{n} s_{i}^{2}\left(1+\left(1-s_{i}\right)\right)$. This indicator combines the features of the index relative and absolute magnitude distribution. Give us the amount of participation of companies with larger shares to the leveling of subjects, weighted by a coefficient that reflects the proportionate size of the rest of the industry. The index is 1 in case of monopoly and is great in the case of participation of major banks in an industry with a large number of banking entities.

Pearson coefficient formula. $r=\frac{n\left(\sum x y\right)-\left(\sum x\right)\left(\sum y\right)}{\sqrt{\left.\left[n \sum x^{2}\right)-\left(\sum x\right)^{2}\right]\left[n \sum y^{2}-\left(\sum y\right)^{2}\right]}}$.

Numerically, the Pearson coefficient is represented in the same way as a correlation coefficient used in a linear regression; ranging from -1 to +1 . Value +1 is the result of a perfect positive relationship between two or more variables. On the other hand, a value of -1 represents a perfect negative relationship. Pearson coefficient may have a small mistake when he used a non-linear equation.

Gini correlation coefficient. Ranging from 1 to 100. As is so close to one of lower concentration is much greater and the higher the concentration. 
Table No.5 Some concentration ratios 2009-2013

(The calculation of these indicators is done by the authors)

\begin{tabular}{|c|c|c|c|c|c|c|c|c|c|c|c|}
\hline $\begin{array}{l}\text { CR4(D+ } \\
\text { Agj) }\end{array}$ & $\begin{array}{l}\text { CR4 } \\
\text { D }\end{array}$ & $\begin{array}{l}\mathrm{CR} \\
4 \mathrm{~K}\end{array}$ & $\begin{array}{l}\text { HH } \\
\text { Id }\end{array}$ & $\begin{array}{l}\text { HT } \\
\text { Id }\end{array}$ & $\begin{array}{l}\mathrm{HH} \\
\mathrm{Ik}\end{array}$ & $\begin{array}{l}\text { HT } \\
\text { Ik }\end{array}$ & $\begin{array}{l}\text { HHIfi } \\
\text { tim }\end{array}$ & $\begin{array}{l}\text { HTIfi } \\
\text { tim }\end{array}$ & $\begin{array}{l}\text { CCId } \\
\text { ep }\end{array}$ & $\begin{array}{l}\text { CCIkr } \\
\text { edi }\end{array}$ & $\begin{array}{l}\text { CCIfit } \\
\text { im }\end{array}$ \\
\hline 48.1 & 68.1 & $\begin{array}{l}55.9 \\
5 \\
\end{array}$ & $\begin{array}{l}0.16 \\
3 \\
\end{array}$ & $\begin{array}{l}0.16 \\
2 \\
\end{array}$ & $\begin{array}{l}0.12 \\
0 \\
\end{array}$ & $\begin{array}{l}0.13 \\
1 \\
\end{array}$ & 0.261 & 0.251 & 0.436 & 0.354 & 0.567 \\
\hline 49.3 & 72 & 62.4 & $\begin{array}{l}0.17 \\
1 \\
\end{array}$ & $\begin{array}{l}0.17 \\
0 \\
\end{array}$ & $\begin{array}{l}0.13 \\
1 \\
\end{array}$ & $\begin{array}{l}0.14 \\
0 \\
\end{array}$ & 0.260 & 0.262 & 0.449 & 0.379 & 0.573 \\
\hline 49.7 & 72.7 & 64.2 & $\begin{array}{l}0.17 \\
9\end{array}$ & $\begin{array}{l}0.17 \\
4\end{array}$ & $\begin{array}{l}0.13 \\
8\end{array}$ & $\begin{array}{l}0.14 \\
4\end{array}$ & 0.256 & 0.255 & 0.461 & 0.393 & 0.562 \\
\hline 50.2 & 67.4 & 60 & $\begin{array}{l}0.15 \\
6\end{array}$ & $\begin{array}{l}0.15 \\
1\end{array}$ & $\begin{array}{l}0.12 \\
4\end{array}$ & $\begin{array}{l}0.12 \\
9\end{array}$ & 0.333 & 0.323 & 0.423 & 0.365 & 0.658 \\
\hline 49.8 & 72.1 & 65.9 & $\begin{array}{l}0.15 \\
7 \\
\end{array}$ & $\begin{array}{l}0.15 \\
8\end{array}$ & $\begin{array}{l}0.13 \\
5 \\
\end{array}$ & $\begin{array}{l}0.14 \\
2\end{array}$ & 0.314 & 0.317 & 0.423 & 0.385 & 0.652 \\
\hline
\end{tabular}

The Gini coefficient for loans and deposits 2009-2013

\begin{tabular}{|l|l|}
\hline Gini.Loan & Gini.Dep \\
\hline 0.465 & 0.563 \\
\hline 0.49 & 0.576 \\
\hline 0.49 & 0.59 \\
\hline 0.484 & 0.543 \\
\hline 0.487 & 0.544 \\
\hline
\end{tabular}

The above data clearly show that Albania does not have a monopolistic competition market structure in the banking system but have an oligopoly market structure type.

3 How have affected the banking system features several leading economic indicator?

Below you will see how they have influenced the features mentioned banking system in several key macroeconomic indicators and the allocation of credit.

In the table below we have the link between the inflation rate and interest rate (REPO), the link between economic growth and real interest rate (REPO), credit growth in the private sector with real growth.

Table no. 6 Some economic indicators and connections between them.

\begin{tabular}{|c|c|c|c|c|c|c|c|}
\hline No & Denominate & 2008 & 2009 & 2010 & 2011 & 2012 & 2013 \\
\hline 1 & Inflation $\%$ & 3.4 & 2.3 & 3.6 & 3.5 & 2 & 1.9 \\
\hline 2 & REPO \% & 6.25 & 5.25 & 5 & 4.75 & 4 & 3 \\
\hline & Pearson Coeficient & \multicolumn{6}{|c|}{$\mathrm{r}=0.6807 \quad \mathrm{R}^{2}=0.4634$} \\
\hline 1 & Real increase of GDP $\%$ & 7.5 & 3.3 & 3.8 & 3 & 1.3 & 0.4 \\
\hline 2 & REPO \% & 6.25 & 5.25 & 5 & 4.75 & 4 & 3 \\
\hline & Koef. kor. Pearson & \multicolumn{6}{|c|}{$\mathrm{r}=0.948 \quad \mathrm{R}^{2}=0.8987$} \\
\hline 1 & Real increase of GDP $\%$ & 7.5 & 3.3 & 3.8 & 3 & 1.3 & 0.4 \\
\hline 2 & $\begin{array}{l}\text { Increase of privat sector } \\
\text { of loans } \%\end{array}$ & 32.2 & 11.7 & 10.6 & 10.4 & 1.5 & -1.21 \\
\hline & Perason Coeficient & \multicolumn{6}{|c|}{$\mathrm{r}=0.9909 \quad \mathrm{R}^{2}=0.9819$} \\
\hline
\end{tabular}

\section{P.s calculations are done by us}


$=$ Interaction between the inflation rate and the interest rate is the same direction. Inflation rate and the interest rate based on the past four years have come in the fall. In fact had the opposite happened. An expansionary monetary policy as expressed in the reduction of the interest rate should have been accompanied by rising inflation. This will happen after the Central Bank expansionary action should have accompanied the commercial banks. They had to lower the rate of interest so that loans become more palatable. Consequently Lek would have run out bank increasing its quantity in circulation. This action will put pressure on the inflation rate. This phenomenon has not occurred because the banks have done with the euro and the dollar to have the interest rate many times lower than the base rate of appreciation. Consequently trasmisionit effect has not happened. This would mean that monetary policy has failed in this indication.

$=$ The link between economic growth and the real rate of interest has the same direction and has come to fall. The opposite should happen. This is because the rate of decline will stimulate investment and investment growth will provoke growing economy. Although in absolute figure increased investment in the economy, their effect has been very low. The reasons will explain below are stressing that are related to the structure and their destination.

$=$ Interaction between the real growth of the economy and private sector credit has the same direction and has come to fall. It is a reflection of the couple's relationship mentioned

above.

What are some of the reasons that credit banks did not properly effectiveness in increasing the Albanian economy

In 2013 the assets of the banking sector increased by 1,234 billion, or a 3.9\% annual spondents. Their growth has been due to the increased volume of government securities and interbank activities.

Despite moderate economic activity, bank deposits grew by 3.6\% during 2013. This increase was lower compared with that of the previous year of $7.3 \%$. During the second half of 2013 , lending activity of the banking sector shrank by $1.8 \%$. At the end of 2013 , lending activity estimated $41.3 \%$ of GDP.

-Lending by sector.

Table no. 7 The distribution of loans by sector in million

\begin{tabular}{|l|l|l|l|l|l|l|l|l|l|l|}
\hline $\begin{array}{l}\text { Denom } \\
\text { inate }\end{array}$ & $\begin{array}{l}\text { Tot. } \\
\text { Loans } \\
\mathrm{ml} / \mathrm{le} \\
\mathrm{kë}\end{array}$ & $\begin{array}{l}\text { Agricul } \\
\text { ture, } \\
\text { Fishin } \\
\mathrm{g}\end{array}$ & $\begin{array}{l}\text { Indu } \\
\text { stry }\end{array}$ & $\begin{array}{l}\text { Ene } \\
\text { rgy, } \\
\text { gaz } \\
\text { wate } \\
\mathrm{r}\end{array}$ & $\begin{array}{l}\text { Constru } \\
\text { ction }\end{array}$ & $\begin{array}{l}\text { Com } \\
\text { erce }\end{array}$ & $\begin{array}{l}\text { Hotels } \\
\text { \& } \\
\text { Restau } \\
\text { rants }\end{array}$ & $\begin{array}{l}\text { Transport } \\
\text { \&Telecomu } \\
\text { nication }\end{array}$ & $\begin{array}{l}\text { Interme } \\
\text { diance }\end{array}$ & $\begin{array}{l}\text { Rea } \\
\text { lty }\end{array}$ \\
\hline 2012 & $\begin{array}{l}401,69 \\
9.10\end{array}$ & 1.6 & 16.3 & 11.6 & 15.8 & 34.3 & 4.3 & 2.9 & 3.3 & 1.5 \\
\hline 2013 & $\begin{array}{l}394,66 \\
0.30\end{array}$ & 1.8 & 16.4 & 12.7 & 13.6 & 33.9 & 4.1 & 3.2 & 3.4 & 0.6 \\
\hline $2014(2)$ & $\begin{array}{l}387,77 \\
2.30\end{array}$ & 1.8 & 16 & 12.9 & 13.8 & 33.9 & 4.1 & 3.2 & 3.0 & 0.6 \\
\hline
\end{tabular}




\begin{tabular}{|l|l|l|l|l|}
\hline Public Administration & Education & $\begin{array}{l}\text { Health, } \\
\text { Social Activities }\end{array}$ & $\begin{array}{l}\text { Individual } \\
\text { collective services }\end{array}$ & Others \\
\hline 0.2 & 1.4 & 1.2 & 3.8 & 1.9 \\
\hline 0.3 & 1.3 & 1.3 & 5.2 & 2.3 \\
\hline 0.3 & 1.3 & 1.1 & 5.2 & 2.9 \\
\hline
\end{tabular}

Fig. Nr. 2 The distribution of loans by branches

\section{The distribution of loans by branches}

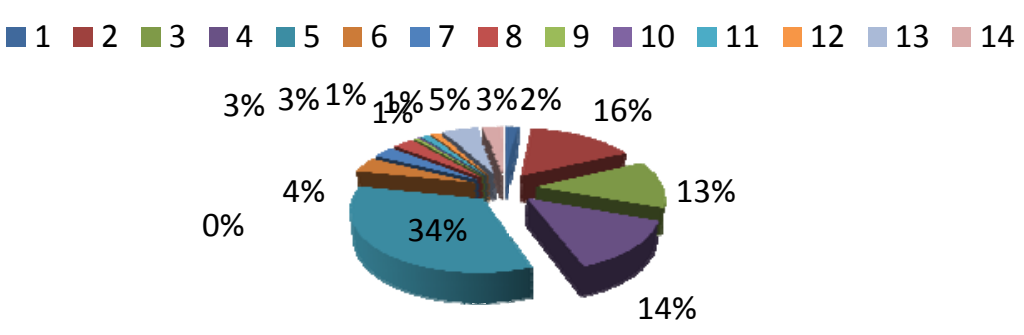

(2014)

Table No.8 Production in\% by main branches

\begin{tabular}{l|l|l|l|l|}
\cline { 3 - 5 } No & \multicolumn{3}{|c|}{ Vitet } \\
\cline { 2 - 5 } 1 & Denominate & 2011 & 2012 & 2013 \\
\cline { 2 - 5 } 2 & Agricultural & $\mathbf{2 0 . 9}$ & $\mathbf{2 0 . 4}$ & $\mathbf{1 7 . 5}$ \\
\cline { 2 - 5 } & Industry & $\mathbf{1 5 . 6}$ & $\mathbf{1 9 . 1}$ & $\mathbf{1 5 . 3}$ \\
\cline { 2 - 6 } & Services & $\mathbf{6 0 . 5}$ & $\mathbf{6 0 . 5}$ & $\mathbf{6 7 . 2}$ \\
\hline
\end{tabular}

Although agriculture has a considerable share in GDP has benefited the smaller loans from the banking system, from $1.5 \%$ to $1.7 \%$ of its total. In 2013 they operated on agriculture although there were only 353,486 farm tractors with tires around 7883, 3064 and 3893 seeding machines cultivators. Reasons why not credited agriculture from commercial banks is that:

- there is a higher risk than other sectors because depends very much on the weather conditions,

- are perishable products,

- there are few transportation options,

- slow return of investment,

- there are few opportunities to control,

- extends the extensive land area is not focused,

- has not stabilized prices,

- there is a high degree of mechanization

- has low degree of management organization, 
- has low levels of educational attainment,

- there is a lack of a new labor etc..

If we had a commercial bank wholly state owned what other policies will apply to this sector by giving priority to certain appropriate moments.

-Lending by districts

Table no. 9 distribution of the loans by districts

Year 2011

2012

2013

Tirana

70.6

71.7

71.7

Durrës

7.8

7.6

7.9

Elbasan

2.9

2.8

3.0

Shkodër

2.5

2.4

2.4

Korçe

1.6

1.6

1.7

Vlora

3.1

3.0

2.9

Fier

3.0

2.5

2.4

Lezha

1.9

2.0

1.7

Others

6.6

6.4

6.3

Figure No. 3 Distribution of loans by districts

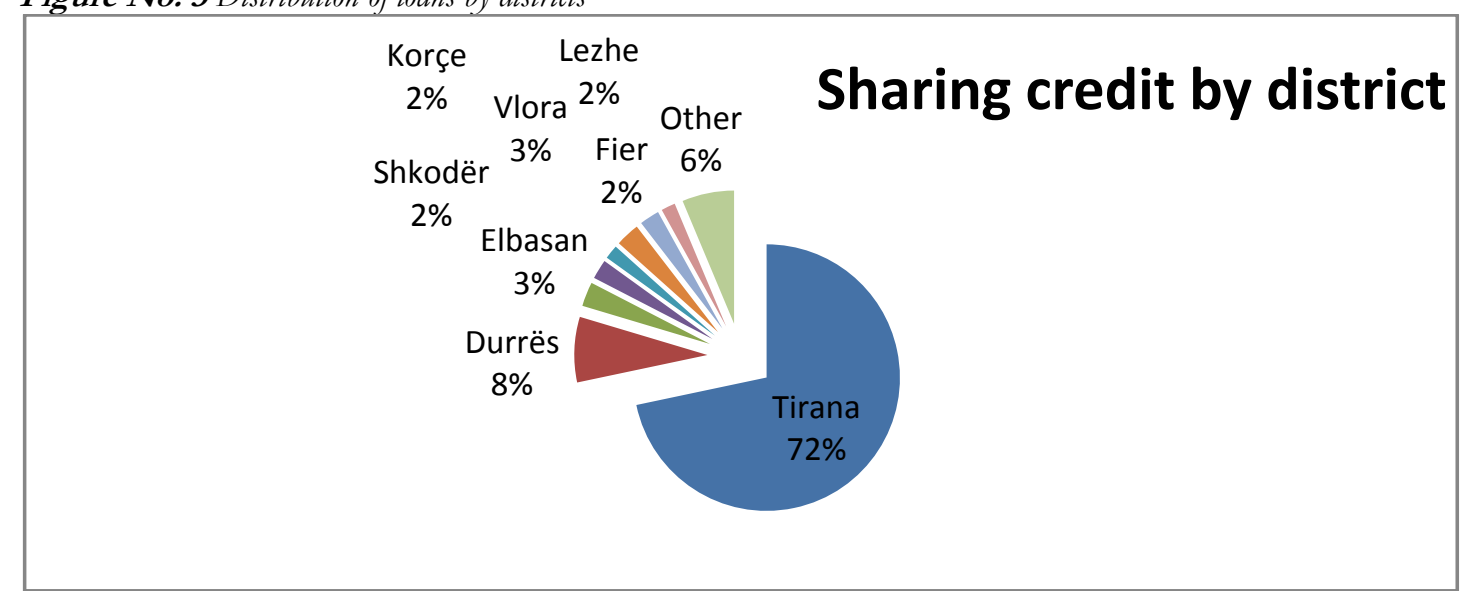

Data from $80 \%$ of the credit is given to the Tirana-Durres while only $20 \%$ is distributed in other regions of Albania. This structure shows an abnormal distribution of loans granted and their concentration closer to the center and generally trade and repairs, construction, hotels, transportation etc.

-Credit in relation to deposits

Table no. 10 Difference in billions Deposits and Loans-Loans-to-deposit ratio in\%

\begin{tabular}{|l|l|l|}
\hline Yars & Dep-Loan & Loan/Dep $\%$ \\
\hline 2009 & 222 & 66.5 \\
\hline 2010 & 302.1 & 61.5 \\
\hline 2011 & 333.3 & 61.9 \\
\hline
\end{tabular}




\begin{tabular}{|l|l|l|}
\hline 2012 & 376 & 59.6 \\
\hline 2013 & 402.2 & 57.7 \\
\hline
\end{tabular}

These reports have graphically shown in the following figure.

Fig.Nr.4 Deposit-loan Difference in billions and credit-deposit ratio in \%

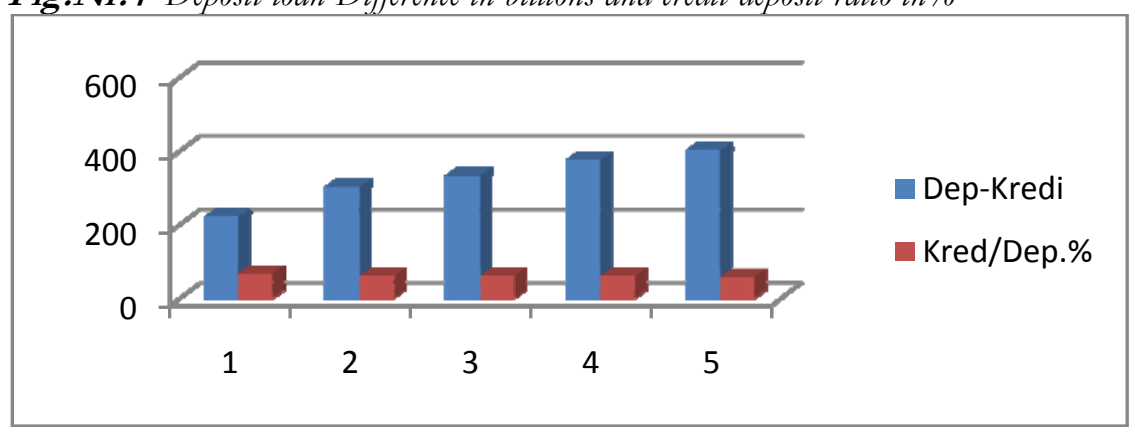

The above data show that deposits are not fully used in the lending sector, but are also used in the purchase of government securities. If this report will refer to ALL then figure would be even lower $44 \%$.

This means that only $44 \%$ of deposits are given in form of a loan and the rest have gone to purchase government securities. Unlike stands loans / deposits ratio in foreign currency. This is a negative indicator for the account of the particularities of the banking market.

\section{Conclusions And Recommendations}

$=$ Albanian banks have a system of early history, it dates back to 1850 and continues until today. We have differentiated into six periods in view of our analysis.

= Among Albania's banking system has a number of features that do not have other regional countries. In Albania, all commercial banks are wholly private, are all a bit foreign to Albanian capital, are about $90 \%$ of their daughter banks and very few of them are parent bank.

$=$ In Bangladesh three coins circulating currency, the euro and the dollar. Their circulation is free, with these coins can be taken loans and deposits can be placed.

$=$ The existence of three coins in circulation and no entirely state-owned bank has made the effectiveness of central bank to be too low in the monetary market. The trasmisionit efetki missing. Decreased interest rate (REPO) is not associated with decreased interest rates on loans, the growth of inflation and GDP. Only 36\% of loans are in ALL and $67 \%$ are in foreign currency, 50\% of deposits are ALL and 50\% in foreign currency.

$=$ Credit is concentrated in two districts in Tirana and Durres

$=$ Are credited branches of commerce, construction and industry. Is left entirely outside the attention of the agricultural sector and agro-processing sector, which accounts for about $20 \%$ although GDP is credited only $1.8 \%$. The conclusion to draw is that the 
privatization of commercial banks has impacted negatively on lending to major sectors of the economy such as agriculture, extraction and processing industry, tourism, etc., and is generally limited to the sectors of trade and repairs.

$=$ Distribution of credit generally shows that the Albanian economy is not based on the appropriate level of credit from commercial banks by creating development disproportions between different districts. It is also one of the reasons it's empty the village as it is funded mostly by immigrants only these areas and less through government subsidies, particularly in agriculture.

\section{Recommendations}

$=$ Recommend opening a bank Agricultural second tier wholly state-owned. This bank will come to your aid and less important sectors such as agriculture credit, agroprocessing, tourism etc.. Will do a better shpërndaqrje between districts of Albania while also helping poorer areas of the country.

$=$ In order to avoid the gradual process of deposit and euro and dollar lending by limiting their impact on the economy and giving more breathing Albanian lek.

\section{Bibliography}

Statistical Report. Bank of Albania. 12/2013. Tirana

Statistical Report. Bank of Albania. 10/2012. Tirana

Statistical Report December 2011. Bank of Albania

Statistical Report August 2010. Bank of Albania

Nëntror 2009 Statistical Report. Bank of Albania

Statistical Report April 2009. Bank of Albania

Statistical Report April 2010. Bank of Albania

Statistical Report. Go 2014. Bank of Albania

"Global recession and its impact on the Albanian economy". Monographs. Alqi Naqellari Robert Maliqi \& Almari Naqellari Tirana 2012.

International Conference of Science in Skopje Alba August 29-31, 2012. "Today the 'economic model of global recession face pressure" A.Naqellari, T.Mehilli \& Living Shaqiri.

Scientific International Conference. ALBANIA AND THE CRISIS: What's next? Revisiting the Growth Model. December 15-16, 2012. "Effect of monetary policy on the Economy up during the global recession from 2008 to 2011". Alqi Naqellari \& Michael Terida

THE FIFTH INTERNATIONAL SCIENTIFIC CONFERENCE "Investment in the function of Economic Development and integration processes.we". Ulcinj april 2013. "Financial System and Its Impact on the New Economy." Alqi Naqellari \& Rushani courageous.

COMPETITION IN THE ALBANIAN BANKING MARKET. Prof.Inordinar Alqi Naqellari, MSc.Elona SHAHINI. 2014.

Albania Open data.

Bank of Albania, according Profit Performance 1993-2013.

Acquisition of Second-Tier Banks 2008-2013

Loans and deposits by currency during 2002-2013

Loan-to-deposit ratio in the Bank 2013 Second Level

Profit Banking System 2003-2013

Credit to business by sector 2007-2013 